\title{
PERJANJIAN PERIKATAN JAUL BELI PERUMAHAN DAN IMLIKASI \\ YURIDISNYA TERHADAP PARA PIHAK DALAM PERSPEKTIF HUKUM \\ PERLINDUNGAN KONSUMEN
}

Oleh :

Hasim Sofyan Lahilote

\begin{abstract}
Abstrak
Ketentuan perikatan dalam KUHP perdata telah menggariskan berbagai hal yang berhubungan denga hak dan kewajiban para para pihak dalam suatu perjanjian, terutama dalam hal kebebasan dalam mengajukan isi kontrak. Akan tetapi realita dalam rimba pelaksanaan kontrak jual beli perumahan cenderung pada penerapan kontrak baku yang telah dibuat dan diajukan oleh developer kepada para konsumen hal ini membuat konsumen menduduki tempat yang marjinal dalam kesempatan tersebut. Dalam makalah ini dideskripsikan kedudukan hokum para pihak dalam suatu kontrak menurut perspektif hokum perlindungan konsumen.
\end{abstract}

Kata kunci: Perikatan, kontrak baku, hokum perlindungan konsumen

\section{A. Pendahuluan}

Sejak zaman purba sampai dengan zaman modern saat ini, manusia membutuhkan umah dam pemukiman sebagai tuntutan dasar manusia yang berbudaya, yang memiliki jati diri atau identitas hunian masing-masing. Sesederhana apapun rumah yang dimiliki seseorang, bisa jadi merupakan sesuatu yang paling berharga, yang pernah dimiliki sebagai tempat tinggal. Inilah yang menjadikan rumah sebagia hal yang mendasar dan juga menjadi prioritas utama dalam kodratnya sebagai mahluk social.

Sebelum terjadinya krisis moniter pada tahun 1997, minat masyarakat untuk memiliki rumah yang siap ditempati begitu besar. Hal ini dimanfaatkan dengan baik oleh para pengembang (developer) sebagia pelaku usaha dibidang perumahan, untuk meraup kuntungan yang sebesar-besarnya. Meskipun rumah yang ditawarkan masih belum jadi bahkan belum dibangun atau masih dalam tahap perencanaan, namun banyak diserbu konsumen oleh karena pemasaran yang begitu gencar oleh pihak pengembang.

Factor-faktor inilah yang mengakibatkan perkembangan bisnis perumahan perlu mendapat perhatian kusus oleh pihak pemerintah untuk menjamin kepentingan rakyat 
banyak, karena yang menjadi sasaran dari pihak pengembang adalah masyarakat pada umumnya. Diharapkan juga terciptanya suatu hubungan bisnis dan hubungan hokum yang menguntungkan dan melindungi pihak pengembang sebagai pelaku usaha dan masyarakat sebagai konsumen, kususnya di bidang perumahan.

Pada kenyataannya, hanya pihak pengembang sebagai pelaku usaha saja yang memperoleh keuntungan dari bisnis jual beli rumah ini. Hal ini jelas-jelas terlihatatau dituangkan dalam Perjanjian Pengikatan Jaul Beli (PPJB) perumahan, yang harus terlebih dahulu dilakukan sebelum melakukan perjanjian lainnya dalam proses jual belih perumahan. Padahal sesungguhnya kedua bela pihak,baik pengembang maupun konsumen mempunyai kedudukan yang sama dimata hokum. Untuk itu diperlukan perangkat hokum yang mengatur dan melindungi kepentingan konsumen dengan tidak mengabaikan kepentingan pihak pelaku usaha sehingga kepentingan keduanya terakomodir dalam perangkat hokum tersebut.

Perlindungan konsumen merupakan hal yang baru dalam peraturan perundangundangan Indonesia, yang timbul seiring dengan kebutuhan masyarakat akan hokum yang menurut mereka dapat melindungi dan member rasa aman seperti yang di amanatkan dalam pembukaan Undang Undang Dasar (UUD) 1945 alinea ke empat yaitu, kemudian dari pada itu untuk membentuk suatu pemerintah Negara Indonesia yang melindungi segenap bangsa Indonesia.

Dari kata melindungi terkandung asas perlindungan hokum bagi segenap bangsa tersebut. Segenap bangsa berarti tidak ada pengecualian didalam.Perlindungan hokum bagi segenap bangsa juga berarti perlindungan yang tanpa terkecuali, baik dia laki-laki ataupun perempuan, orang kaya atau miskin, warga pribumi atau warga keturunan dan pengusaha atau konsumen. Dari hal diatas dapat diketahui bahwa hal yang menyangkut perlindungan konsumen adalah merupakan hak dari seluruh warga Negara yang tidak pernah bisa berhenti menjadi konsumen sesuai dengan kodratnya sebagai makhluk social.

Dalam perkembangan selanjutnya dirasakan perlu untuk membuat suatu produk perundang undangan yang secara khusus mengatur tentang perlindungan konsumen. Hal ini timbul karena banyaknya keluhan-keluhan dari pihak konsumen pengguna barang atau jasa yang dirugikan.

Disisi lain perlindungan pada kegiatan usaha tampaknya, relative lebih cepat disediakan. Tidak demikian halnya dengan peraturan mengenai perlindungan terhadap 
konsumen. Padahal sesungguhnya konsumen sama kedudukannya dengan dengan pengusahan dan terutama sebagai penyerap hasil usaha kegiatan pengusaha tersebut.

Semacam sudah menjadi kebiasaan, mayoritas konsumen di Indonesia ketika berhadapan dengan pelaku usaha cenderung bersikap pasrah walaupun hak-haknya sebagai konsumen sudah diinjak-injak. Hal ini disebabkan oleh kurangnya pengetahuan masyarakat akan hak-haknya sebagai konsumen, sehingga sama sekali tidak ada usaha untuk menuntut hak tersebut dan mengupayakan, posisi yang seimbang antara pelaku usaha dan konsumen. Konsumen pada umumnya baru berani berteriak, menulis surat pembaca di Koran, ataupun melakukan hal yang lain apabilah suda mengalami penderitaan dan kerugian yang besar. Persepsi seperti inilah yang perlu diubah sehingga tericpta hubungan hokum yang sehat antara pelaku usaha dan konsumen.

\section{B. Pembahasan}

Salah satu instrument perlindungan di bidang perumahan, karena kebutuhan akan rumah bagi seluruh lapisan masyarakat merupakan salah satu kebutuhan pokok yang harus dipenuhi sebaik-baiknya. Dalam urusan jual beli rumah, pemasarannya menggunakan sarana iklan atau brosur untuk mengkomunikasikan produk produk yang dibuat untuk dipasarkan oleh pengembang, kepada konsumennya. Begitu gencarnya pemasaran, tak jarang infirmasi yang di sampaikan itu ternyata tidak benar atau menyesatkan. Padahal konsumen sudah terlanjur menyetujui dan menandatangani Perjanjian Pengikatan Jual Belih (PPJB) dengan pengembang dan atau bahkan suda mengambil Kredit Pemilikan Rumah (KPR) di bank.

Masalah kemudian muncul jika pihak konumen sudah menyetujui dan menandatangani PPJB, dan yang dilanjutkan dengan pembuatan akta jual belih rumah tersebut dihadapan notaries, kemudian apa yang ternyata diharapkan oleh konsumen mengenai janji-janji di brosur/iklan ternyata tidak dipenuhi oleh pelaku usaha. Sebagai contoh, di dalam iklan mengatakan bahwa perumahan yang dijanjikan tersebut memiliki fasilitas olah raga, tempat ibadah, dan juga termasuk fasilitas listrik, telepon, dan penyediaan air bersih, tetapi dalam kenyataannya bukanlah demikian, atau di iklankan oleh pelaku usaha bahwa daera perumahan yang ditawarkan adalah daera bebas banjir, tetapi setelah rumah tersebut dihuni beberapa lama, kemudian turun hujan deras dan ternyata perumahan tersebut mengalami kebanjuran. Belum lagi kondisi fisik rumah yang perbandingan campuran semennya tidak benar yang mengakibatkan dinding dan lantai rumah pecah-pecah. Hal ini jelas jelas merugikan konsumen. 
Proses terjadinya kesepakatan antara pihak pengembang dan konsumen perumahan dituangkan kedalam satu bentuk perjanjian yang disebut Perjanjian Pengikat Jual Beli (PPJB) atau nama lainnya bisa disebutkan seperti : Perjanjian Pendahuluan Pembelian, Perjanjian Akan Jual beli, dan sebagainya. PPJB ini merupakan kesepakatan mula-mula antara pihak pengembang dan konsumen, yang didalmnya berisi klausula-klausula penyangkut perjanjian kedua bela pihak kenyatannya PPJB ini disusun sepihak oleh pihak pengembang sebagai pelaku usaha yang tidak memungkinkan adanya perundingan atau negosiasi para pihak untuk menemukan suatu kesepakatan.

Dari segi hubungan hokum, adanya bentuk perjanjian yang hanya dibentuk oleh satu pihak saja dimaksutkan agar terciptanya kepraktisan serta penghematan waktu untuk menemukan kesepakatan para pihak dalam perjanjian tersebut. Dalam prakteknya telahdisdiakan formulir-formulir standar, jadi ini merupakan suatu perjanjian baku (standard contrct).

\section{Tanggung Gugat Produk (Product Liability)}

Tanggung gugat produk adalah suatu istilah yang ditejemahkan dari bahasa inggris yaitu product Liability dan Ansprakelikheid. Dalam terminologi hukum nasional doktrin Product Liability yang, menerjemahkan sebagai tanggung gugat produk dan ada juga yang mengartikan sebagai tanggung jawab produk. ${ }^{1}$

Pada makalah ini kmi menggunakan istilah tanggung gugat dan bukan tanggung jawab karena tanggung gugat lebih tepat untuk lapangan keperdataan sedangkantanggung jawab lebih tepat untuk lapangan hokum pidana yang mana tanggung jawab merupakan padanan dari kata bahasa Inggris Responsibility atau dalam bahasa belanda adalah Verantwodelykheid.

Dalam Undang-Undang No. 8 tahun 1990 fidak ditemukan definisi atau pengertian dari liability dimana dalam undang-undang tersebut liability diartikan sebagia tanggung jawab. Prinsip tanggung jawab dalam hokum perdata dapat digolongkan dalam dua jenis:

1. Kesalahan (Leability based on fault) pasal 1365 BW. Subjek pelaku kesalahan tersebut dapat bertanggung gugat berdasarkan doktrik hokum (Vicalovs liability dan corporate habilio).

\footnotetext{
${ }^{1}$ Gunawan Widjaya \& Ahmad yani, Perlindungan konsumen (Jakarta: Gramedia Pustaka Utama, 2000), h. 23
} 
2. Prinsip praduga untuk selalu bertanggung gugat (presumption of liability principle). Dalam prinsip ini tergugat selalu dianggap bertanggung gugat sampai ia dapat membuktikan ia tidak bersalah (beban pembuktian pada sitergugat). ${ }^{2}$

Perhatyian terhadap konsumen terutama, di amerika Serikat (1960 an s/d 1970 an) mengalami perkembangan yang signifikan dan menjadi objek kajian di bidang ekonomi, social, politik, dan hokum, dimana pada era tahun-tahun tersebut berhasil diundangkan banyak sekali peraturan dan dijatuhkan putusan-putusan hakim yang memperkuatkeadaan konsumen. Di Indonesia gerakan perlindungan konsumen menggema dari gerakan-gerakan serupa di Amerika Serikat.

Di Indonesia masalah perlindungan konsumen baru mulai terdengar pada tahun 1970 an, yang ditandani dengan lahirnya Yayasan Lembaga Konsumen Indinesia (YLKI) bulan Mei 1973.

Secara historis pada awalnya yayasan ini berkaitan dengan rasa mawas diri terhadap promosi untuk memperlancar barang-barang dalam negeri, dan atas desakan suara-suara masyarakat bahwa kegiatan promosi ini harus diimbangi dengan langka-langka pengawasan, agar masyarakat tidak merasa dirugikan dan kualitasnya terjamin. Adanya keinginan masyarakat untuk melindungi dirinya dari barang yang rendah mutunya telah memacu untuk memikirkan secara sungguh-sungguh usaha untuk melindungi konsumen, dan mulailah gerakan untuk merealisasikan cita-cita ini.

Di tinjau dari kemajuan peraturan perundang-undangan di Indonesia Mengenai perlindungan konsumen, sampai saat ini bisa dikatakan sangat minim, baik dilihat dari kuantitas peraturannya maupun kedalam materi yang dicakupinya. Kenyataan tersebut memotifasi gerakan konsumen di idnonesia, termasuk yang di prakarsai oleh YLKI untuk membawa naskah akademik Undang-undang Perlindungan Konsumen ke Dewan Perwakilan Rakyat.

Perkembangan baru di bidang perlindungan konsumen, yaitu takala Undang-Undang Nomor 8 tahun 1999 Tentang Perlindungan Konsumen (UUPK) disahkan dan diundangkan pada 20 Aril 1999. UUPK ini masih memerlukan waktu satu tahun untuk berlaku efektuf. Tanpa mengurangi penghargaan terhadap upaya terus menerus yang digalang YLKI, andil

\footnotetext{
${ }^{2}$ Ibid
} 
terbebar yang memaksa kehadiran UUPK adalah juga karena cukup kuatnya tekanan dari dunia internasional, dimana setelah pemerintah Republik Indonesia mengeahkan Undangundang Nomor 7 Tahnu 1994 terntang Agrement Estabilising The World Trade Organization (apersetujuan Pembentukan Organisasi Pedangan Dunia), maka ada kewajiban bagi Indonesia untuk mengikuti standar-standar hokum yang berlaku dan diterima luas oleh Negara Negara anggota WTO. Salah satunya adalah perlunya eksistensi UUPK. Istilah konsumen berasal dari kata Consumer (Inggris Amerika), atau Consument I Konsument (Belanda ). Pengertian dari Consumer atau Consument itu tergantung dalam posisi mana dia berada. Secara harfiah consumer itu adalah lawan dari produsen setiap orang yang menggunakan barang. Tujuan pengguna barang atau jasa itu nanti menentukan termasuk konsumen kelompok mana pengguna tersebut. Begitu pula arti kata consumer "pemakaian atau Konsumen"3 sedangkan menurut pasal 1 dan 2 UUPK, konsumen adalah setiap orang pemakai barang dan/atau jasa yang tersedia dalam masyarakat, baik untuk kepentingan diri sendiri, keluarga, orang lain maupun mahluk hidup lain, dan tidak untuk diperdagangkan. Pada penjelasan pasal 1 ayat 2 UUPK tersebut dikatakan bahwa konsumen ahir adalah pengguna atau pemanfaat ahir suatu produk, sedangkan konsumen antara adalah konsumen yang menggunakan suatu produk sebagai bahan dari proses produksi atau produk lainnya. Pengertian konsumen dalam Undang-undang ini adalah konsumen akhir.

Mantan Presiden Amerika Serikat, Jolin F. Kennedy, perna mengemukakan \$ hal dasar konsumen, yaitu:

1. Hak untuk mendapatkan keamanan (free right to safety)

2. Hak untuk mendapatkan informasi (The right to be informed)

3. Hak untuk memilih (The Right to choose)

4. Hak untuk didenganr (The right to be heard)

Empat hal dasar inidiakui secara internasional. Dalam perkembangannya, Organisasiorganisasi konsumen yang tergabung dalam The Internasional Organization of Consumer IInjon IOCV) menambahkan lagi beberapa hak, seperti bak mendapatkan pendidikan konsumen, hak mendapatkan ganti kerugian, dan hak mendapatkan lingkungan hidup yang baik dan sehat.

\footnotetext{
${ }^{3}$ Sudaryatmo, Masalah Perlindungan Konsumen di Indonesia, (Bandung Citra Aditya Bhakti, 1996), h.35.
} 
Dari keempat hak pokok diatas keamanan konsumen merupakan hal yang paliing pokok ddan utama dalam perlindungan konsumen. Barang dan/atau jasa yang dalam menggunaanya tidak memberikan kenyamanan, terlebih lagi yang tidak aman atau membahayakan keselamatan konsumen jelas tidak layak untuk diedarkan dalam masyarakat. Selanjutnya untuk menjamin bahwa suatu barang dan/atau jasa dalam penggunannya akan aman, nyaman, dan tidak membahayakan konsumen penggunaannya, maka konsumen diberikan hak untuk memilih barang dan/atau jasa yang dikehendakinya berdasarkan atas keterbukaan informasi yang benar, jelas dan jujur. Terkadang penyimpangan yang merugikan, konsumen berhak untuk didenganr, memperoleh advokasi, pembinaan, perlakuan yang adil, kompensasi sampai gantirugi.

Selainmemiliki hak-hak yang di atur dalam apasal 14 UUPK konsumen juga mempunya kewajiban yang harus dipenuhi yang dijelaskna dalam pasal UUPK sebagai berikut:

a. Membaca atau mengikuti petunjuk infimasi dan prosedur pemakaian atau pemanfaatan barang dan/atau jasa demi keamanan dan keselamatan

b. Beritikan baik dalam memperlakukan Transaksi pembelian barang dan/atau jasa

c. Membayar sesuai dengan nilai tukar yang disepakati

d. Mengikuti upaya penyelesaian hokum sengketa perlindungan konsumen secara patut.

Hal ini dimaksut agar tercipta suatu hubungan hokum yang sehat antara pihak konsumen maupun pelaku usaha.

1. Perjanjian

a. Pengertian perjanjian

Pada umumnya dalam pasal 11313 KUH Perdata mendefinisikan perjanjian adala suatu perbuatan dimana satu orang atau lebih mengikatkan diri pada satuorang atau lebih. Selanjutnya subekti mengatakan bahwa suatu perjanjian adalah suatu peristiwa dimana seorang berjanji kepada seorang yang lain atau diaman dua orang itu saling berjanji untuk melaksanakan sesuatu hal. ${ }^{4}$

\footnotetext{
${ }^{4}$ R. Subekti Hukum Perjanjian, (Jakarta, Intermasa, 1986), h. 10.
} 
Perjanjian merupakan sumber terpenting yang melahirkan perikatan. Memang perikatan itu paling banyak diterbitkan oleh suatu perjanjian, tetapi sebagaimana dikatakan tadi, ada juga sumber-sumber lain yang melahirkan perikatan. Sumber-sumber lain ini tercakup dengan nama undang-undang. Jadi, ada perikatan yang lahir dari perjanjian dan ada perikatan yang lahir dari Undang-undang. ${ }^{5}$

Kemudian agar bisa dikatakan bahwa perjanjian itu sah, maka hal ini harus disesuakan dengan apa yang teruat dalam apsal 1320 KUHPerdata, yang mengatakan bahwa untuk sahnya suatu perjanjian diperlukan 4 (empat( syarat, yaitu :

1. Kesepakatan mereka yang mengikatkan dirinya

2. Kecakapan untuk membuat suatu perjanjian.

3. Mengenai suatu hal tertentu.

4. Suatu sebab yang tidak terlarang.

b. Perjanjian Pengikatan Jual Beli (PPJB) Perumahan

Bila member rumah atau rumah susun seoran gkonsumen pasti akan menjumpai dokumen dokumen hokum (Legal Dokuments)yang penting yaitu:

1. Perjanjian Pengikat Jual Beli, disingkat (PPJB), atau nama lainnya seperti:

Perjanjian Pendahulu Pembelian, Perjanjian Akan Jual Beli antara pengembang dan konsumen.

2. Akta Jual yang dibuat dan ditandatangani dihadapan Pejabat Pembuat Akta Tanah (PPAT) untuk mengalihkan atau memecah pemilikan tanah dan rumah dari pengembang kepada setiap konsumen.

3. Perjanjian Kredit Pemilikan Rumah dari bank pemberi KPR. ${ }^{6}$

Dokumen yang pertama merupakan dokumen yang membuktikan adanya hubungan hokum (hubungan kontraktual) antara pengembang dan konsumen, dimana pengembang

\footnotetext{
5 ibid

${ }^{6}$ Yusuf Shofie, Perlindungan Konsumen dan Instrumen-instrumen Hukumnya, (bandung Citra Aditya Bakti, 2000),h.27.
} 
mengikatkan diri untuk menjual rumah dan tanah kepada konsumen, sedangkan konsumen menjual membeli rumah dari pengembang dengan kewajiban membayar harga jualnya dalambentuk angsuran uang muka (Down Payment) dan sisanya diselesaikan dengan fasilitas KPR.

Dokumen yang kedua terjadi sebagai akibat dari terciptanya kata sepakat pada penrjanjian pengikat jual beli (PPJB). Kalau pada dokumen pertama hanya dimaksutkan untuk mengikat perjanjian antara pihak pengembang dan konsumen dalam melakukan kewajibannya masing-masing sebagaimana yang tertuang dalam PPJB tadi, maka dokumen yang keduaadalah realisasi dari apa yang diperjanjikan dalam PPJB tadi.

Sedangkan dokumen yang ketiga menunjukan adanya hubungan hokum antara konsumen dengan pihak bank pemberi KPR. Didalamnya antar lain diatur jumlah pinjaman. Jangka waktu pelunasan KPR, besarnya atau system perhitungan bunga pinjaman. Sebagaimana lazimnya pada setiap setiap pembuatan perjanjian yang semata-mata berlandaskan pada asas kebebasan berkontrak, maka juga pada PPJB masing-masing pihak berusaha untuk menciptakan dominasi pada pihak lainnya.

Dalam kenyataannya PPJB ini hanya disusun secara sepihak oleh pengembang sehingga tidak ada kemungkinan bagi konsumen untuk bernegosiasi tenang isi perjanjian itu. Perjanjian yang hanya disusun oleh sala satu pihak saja selanjutnya lebih popular dengan namaperjanjian baku (Sandard Contract).

Perjanjian baku ini banyak sekali dipakai dalam berbagai macam perjanjian dilapangan dunia usaha. Karena sifatnya yang praktis, jenis perjanjain ini banyak sekali disukai para pelaku usaha diberbagai bidang baik dibidang perumahan, jasa perbankan, perdagangan, asuransi, dll untuk lebih bersinergikan kegiatan usaha yang bersifat mudah sehingga dapat mengehat waku dan biaya yang mungkin akan timbul bila kita menggunakan jenis perjanjian yang dikehendaki oleh KUHPerdata. Sebab didalam perjanjian baku ini konsumen tinggal menandatangani akta perjanjian atau menerima begitu saja nota jual beli tanpa mengadakan negosiasi antara penjual dan pembeli sebagaimana yang di amanatkan dalam KUHPerdata sehingga dikemudian hari apabila timbul wanprestasi dari pihak pelaku usaha, posisi konsumen untuk mengadakan klaim kerugian kepada pelaku usaha berada pada posisi yang sangat lemah karena telah menanda tangani surat perjanjian tersebut atau telah menerima nota jula beli tersebut. Sehingga bila terjadi sengketa dipengadilan nanti, 
konsumen tersebut akan dikalahkan oleh para pelaku usaha karena mereka mempunyai bukti yang cukup kuat yang ditanda tangani oleh konsumen tersebut.

Dengan adanya Undang-undang nomor 8 tahun 1999 tentang Perlindugan Konsumen yang secara substantive telah dapat mengakimidasi kepentingan para konsumen diseluruh Indonesia, diharapkan praktek-praktek seperti yang telah tersebut diatas dapat dihilangkan dalam dunia perdagangan atau paling tidak di minimalisasi keadaannya sehingga nantinya klaim-klaim kerugian yang diakibatkan oleh praktek perjanjian baku dapat dihilangkan sehingga tercipta iklim usaha kondusif yang menguntungkan kedua bela pihak baik para pelaku usaha dalam hal ini pengembang, maupun para konsumen.

\section{Kesimpulan}

Denagn adanya pengesahan Undang-undang nomor 7 Tahun 1994 tentang Agrement Estabilishing The World Trade Organization (Persetujuan Pembentukan Organisasi Perdagangan Dunia), Maka Negara Indonesia mempunyai kewajiban untuk mengikuti standar-Standar hokum yang berlaku dan diterima luas oleh Negara anggota WTO.

Akibat dari adanya pengesahan undang-undangtersebut ditetapkanlah undang-undang nomor 8 tahun 1999 tentang perlindungan konsumen (UUPK) yang secra substatif berjuang untuk melindungan kepentingan konsumen dalam dunia perdagangan.

Dengan adanya UUPK ini, para konsumen dapat menuntut klaim kerugian kepada para pelaku usaha sepanjang apa yang diperjanjikan dalam kontrak tersebut tidak dipenuhi oleh pelaku usaha. Dengan adanya UUPK ini, para pelaku usaha, kususnya para pengembang (developer) perumahan, disyaratkan tidak lagi menerpkan system perjanjian baku (standart contrac) yang pada prinsipnya merugikan para konsumen dalam dunia perdagangan.

Pengembang (developer) perumahan harus bertanggung gugat terhadap berbagai klaim kerugian yang ditimpahkan kepadanya oleh para konsumen bila terjadi wanprestasi terhadap kontrak yang telah disepakati bersama. 


\section{Daftar Pustaka}

Gunawan Wijaya \& Ahmad Yani, Perlindungan Konsumen , Jakarta, Gramedia Pustaka Utama, 2000

Shofie, Yusuf, Perlindungan Konsumen dan Instrumen-instrumn Hukumnya, Bandung, Citra Aditya Bakti, 2000

Sudaryatmo, Masalah Perlindungan Konsumen di Indonesia, Bandung, Citra Aditya Bakti, 1996

Subekti, R. Hukum Perjanjian, Jakarta, Intermasa, 1986.

Undang-Undang Nomor 8 Tahun 1999 tentang Perlindungan Konsumen.

Kitab Undang-Undang Hukum Perdata. 